\title{
Molecular Cloning and Characterization of the Constitutive Bovine Aortic Endothelial Cell Nitric Oxide Synthase
}

\author{
Ken'ichi Nishida, David G. Harrison, Jorge P. Navas, Ari A. Fisher, Sheila P. Dockery, \\ Masaaki Uematsu, * Robert M. Nerem, * R. Wayne Alexander, and T. J. Murphy \\ Cardiology Division, Emory University School of Medicine, the Atlanta Veterans Administration \\ Medical Center, Atlanta, Georgia 30322; and *Georgia Institute of Technology, Atlanta, Georgia 30332-0404
}

\begin{abstract}
The constitutive endothelial cell nitric oxide synthase (NOS) importantly regulates vascular homeostasis. To gain understanding of this enzyme, a pEF BOS cDNA library of $5 \times 10^{5}$ clones was prepared from bovine aortic endothelial cells (BAEC) and screened with a 2.8-kb cDNA BamHI fragment of rat brain NOS. Clone pBOS13 was found to express NO synthase activity when transfected into COS-7 cells. Sequence analysis revealed sequences compatible with binding domains for calcium/calmodulin, flavin mononucleotide, flavin adenine nucleotide and NADPH. The deduced amino acid sequence revealed a protein with a relative mol mass of 133,286 , which is $58 \%$ homologous to the rat cerebellar NOS and 51\% homologous to the mouse macrophage NOS. The amino-terminal portion of the protein exhibits several characteristics peculiar to the endothelial cell NOS. These include a proline-rich region and several potential sites for proline-directed phosphorylation as well as a potential substrate site for acyl transferase. Northern hybridization to mRNA from cultured BAEC revealed an abundant 4.8-kb message, which was not increased by coincubation with tumor necrosis factor $\alpha$, but was markedly increased by exposure to shear stress for $24 \mathrm{~h}$. The unique features of the endothelial cell NO synthase, particularly in the amino terminal portion of the molecule, may provide for novel regulatory influences of enzyme activity and localization. ( $J$. Clin. Invest. 1992. 90:2092-2096.) Key words: COS-7 cells • cDNA • flavin nucleotide binding • shear stress • tumor necrosis factor $\alpha \bullet$ proline directed phosphorylation $\bullet$ myristoylation
\end{abstract}

\section{Introduction}

The endothelium-derived relaxing factor has been shown to be either nitric oxide (1) or a closely related compound (2) that is synthesized from the guanidino nitrogens of arginine ( 3 ). The enzyme responsible for the production of nitric oxide from arginine, nitric oxide synthase (NOS) ${ }^{1}$ has recently been iden-

Address correspondence to David G. Harrison, M.D., Cardiology Division, PO Box LL, Emory University School of Medicine, Atlanta, GA 30322. 1992.

Received for publication 11 June 1992 and in revised form 30 July

1. Abbreviations used in this paper: BAEC, bovine aortic endothelial cells; L-NMMA, L- $N$-monomethyl arginine; NOS, nitric oxide synthase; SSC, standard saline citrate; TNF $\alpha$, tumor necrosis factor $\alpha$.

The Journal of Clinical Investigation, Inc.

Volume 90, November 1992, 2092-2096 tified not only in the endothelium, but also in cerebellum (4), macrophage (5), and neutrophils (6). NO synthesis requires tetrahydrobiopterin $(7)$, flavin adenine nucleotide $(8,9)$, and NADPH as cofactors (10). The brain and endothelial cell enzymes require calcium and calmodulin $(11,12)$, while the role of these regulatory factors in the macrophage and neutrophil are less well defined $(9,13)$. The brain NO synthase is cytosolic in location (9), while the endothelial cell enzyme is predominantly membrane bound (14). Recently, the brain and macrophage NO synthase cDNAs have been cloned and amino acid sequences determined (15-17). The numerous differences between the brain, macrophage, and endothelial cell NOS suggest that the molecular structures of these isoforms are different.

To characterize the endothelial NOS, we have isolated its cDNA from bovine endothelial cells and determined its nucleotide and deduced amino acid sequence. As an initial approach to explaining its regulatory features, we have demonstrated that expression of NO synthase mRNA is enhanced by exposure to increased shear stress.

\section{Methods}

cDNA Library Screening. Poly A(+) RNA was prepared from cultured bovine aortic endothelial cells (BAEC) and cDNA synthesized using both oligo-dT and random hexamer primers (Superscript Choice System; Gibco-Bethesda Research Laboratories, Gaithersburg, MD). After ligation with BstXI adapters, the size-fractionated cDNA was ligated into the BstXI sites of the pEF-BOS expression vector (18). A 5 $\times 10^{5}$ independent clone library was obtained after electrotransformation of Escherichia coli DH5 $\alpha$. The library was screened by colony hybridization using a 2.8-kb BamHI fragment (representing nucleotides 1830-4641) from the rat brain NO synthase cDNA (15) (provided by Dr. David Bredt, Dept of Neuroscience, Pharmacology, and Molecular Science, Johns Hopkins University, Baltimore, MD), which was labeled with $\left[\alpha^{32} \mathrm{P}\right] \mathrm{dCTP}$ using the random primer method and T7 DNA polymerase. Hybridization was performed overnight on nitrocellulose membranes at $42^{\circ} \mathrm{C}$ in $6 \times$ standard saline citrate (SSC), $5 \times$ Denhardt's solution, $50 \%$ formamide, $0.5 \%$ SDS, and $10 \mu \mathrm{g} / \mathrm{ml}$ sheared salmon sperm DNA. These were washed at $52^{\circ} \mathrm{C}$ in $2 \times \mathrm{SSC}$, $0.1 \%$ SDS and exposed to X-AR film. Hybridizing colonies were purified by successive rounds of screening and overlapping clones identified by restriction enzyme analysis. cDNA inserts from isolated clones of pBOS 4.1 and pBOS-13 were subcloned into pBluescript and nested deletions were prepared using exonuclease III. Both strands of cDNA were sequenced by the dideoxy chain termination method (19) using a Sequenase kit (U.S. Biochemical Corp., Cleveland, $\mathrm{OH}$ ) according to the manufacturer's directions. Clone pBOS-13 was isolated from the library using a 0.9-kb SstI fragment from the $5^{\prime}$ end of the clone pBOS 4.1.

Expression of NO synthase. COS-7 cells were grown to confluence in 3.5-cm plates in DMEM and 10\% FCS plus penicillin and streptomycin. At the time of transfection, the medium was replaced with a 
reduced serum medium, (Opti-MEM I; Gibco-Bethesda Research Laboratories) and $20 \mu \mathrm{g}$ of plasmid DNA and $50 \mu \mathrm{g}$ lipofection reagent (Gibco-Bethesda Research Laboratories, $1 \mu \mathrm{g} / \mathrm{ml}$ ) were added to the media for $24 \mathrm{~h}$. NO synthase activity was measured $48 \mathrm{~h}$ thereafter.

NO synthase activity was measured by examining production of nitrite, the stable degradation product of nitric oxide, by transfected COS-7 cells. Cells were washed gently three times with a modified Krebs/Hepes buffer (composition [mM]: $\mathrm{NaCl} 99.0, \mathrm{KCl} 4.69, \mathrm{CaCl}_{2}$ 1.87, $\mathrm{MgSO}_{4} 1.2, \mathrm{NaHCO}_{3} 25, \mathrm{~K}_{2} \mathrm{HPO}_{4}$, Na-Hepes 20, D-glucose 11.1), and then incubated in $2 \mathrm{ml}$ of the Krebs/Hepes buffer with or without $1 \mu \mathrm{M}$ calcium ionophore $\mathrm{A} 23187$ at $37^{\circ} \mathrm{C}$ for $1 \mathrm{~h}$. In some experiments, $100 \mu \mathrm{M} \mathrm{L}-N$-monomethyl arginine (L-NMMA) was added to the buffer. To measure nitrite content, 500- $\mu 1$ aliquots of the buffer from the COS-7 cells were placed in 2-ml vials and sealed with an aluminum and Teflon cap. The samples were then purged of oxygen using nitrogen gas via needles inserted through the Teflon. Nitrite was converted to NO gas by the addition of a excess of $5 \% \mathrm{NaI}$ and trichloroacetic acid. The samples were then purged with a stream of nitrogen gas that was directed via vacuum into the reaction chamber of a chemiluminescence nitric oxide analyzer. The chemiluminescence analyzer was calibrated daily using nitrite standards.

In separate experiments, a monoclonal antibody directed against the BAEC NO synthase was used to examine enzyme expression by transfected and nontransfected COS-7 cells. Homogenates of COS-7 cells were suspended in $50 \mathrm{mM}$ containing $5 \mu \mathrm{g} / \mathrm{ml}$ PMSF. Protein content was determined using a modified Bradford assay (20). $10 \mu \mathrm{g}$ protein was size-fractionated electrophoretically using $7.5 \%$ SDS polyacrylamide gel. The proteins were transferred to a nitrocellulose membrane blocked with $5 \%$ casein Tris-buffered saline solution containing $1 \%$ Tween (TBS-T) at $22^{\circ} \mathrm{C}, \mathrm{pH} 7.6$. The membranes were then incubated overnight with a 1:1,000 dilution of murine monoclonal antibody, mAb H32 (21), directed against the BAEC NO synthase (kindly provided by Jennifer Pollock and Ulrich Förstermann, Vascular Biology Group, Abbott Laboratories, Abbott Park, IL) in TBS-T. The membranes were subsequently incubated with a goat anti-mouse secondary antibody conjugated to horseradish peroxidase (Amersham Corp., Arlington Heights, IL). Excess antibody was removed by sequential washings with TBS-T. Signals were detected using the ECL detection system (Amersham Corp.) on standard $\mathrm{x}$-ray film.

Regulation of NO synthase expression. To test the hypothesis that shear stress may modulate expression of NO synthase mRNA, BAEC were grown on mylar sheets to confluence as previously described (22). Subsequently, the cells were placed in a specially designed parallel plate chamber designed to allow the application of precise quantities of steady state shear. Cells were exposed for $24 \mathrm{~h}$ to either no shear or to a shear stress of $15 \mathrm{dyns} / \mathrm{cm}^{2}$. The cells were then lysed in guanidinium isothiocyanate and total RNA was isolated using phenol extraction. Total RNA $(20 \mu \mathrm{g})$ was size-fractionated on a $1.0 \%$ agarose $/ 3 \%$ formaldehyde gel and transferred to a nitrocellulose membrane. Hybridizations were performed overnight using a $\left[{ }^{32} \mathrm{P}\right] \mathrm{dCTP}$ labeled, random primed, 2.1-kb cDNA fragment from clone pBOS 2.1 (Fig. 1 ) at $42^{\circ} \mathrm{C}$, $50 \%$ formamide, $10 \mu \mathrm{g} / \mathrm{ml}$ sheared salmon sperm DNA in $6 \times \mathrm{SSC}, 5 \times$ Denhardt's solution, and $0.5 \%$ SDS. The membranes were then washed for 30 min twice at $42^{\circ} \mathrm{C}, 2 \times \mathrm{SSC}, 1 \% \mathrm{SDS}$, and subsequently at high stringency for $30 \mathrm{~min}$ once at $65^{\circ} \mathrm{C}$ using $0.2 \times$ SSC and $0.1 \%$ SDS.

In a separate study, NO synthase protein content of BAEC exposed to either static conditions or to shear stress was examined using Western analysis as described in the studies of NO synthase expression in COS-7 cells.

In separate experiments, $100 \mathrm{U} / \mathrm{ml}$ tumor necrosis factor $\alpha$ (TNF $\alpha$ ) (Boehinger Mannheim, Indianapolis, IN) was added to the medium of BAEC grown in T-75 flasks for $24 \mathrm{~h}$ before isolation of total RNA for Northern analysis of NO synthase expression, as described above.

In all studies of NO synthase mRNA expression, the nitrocellulose membranes were stripped and subsequently hybridized with a cDNA for GAPDH to serve as a control.

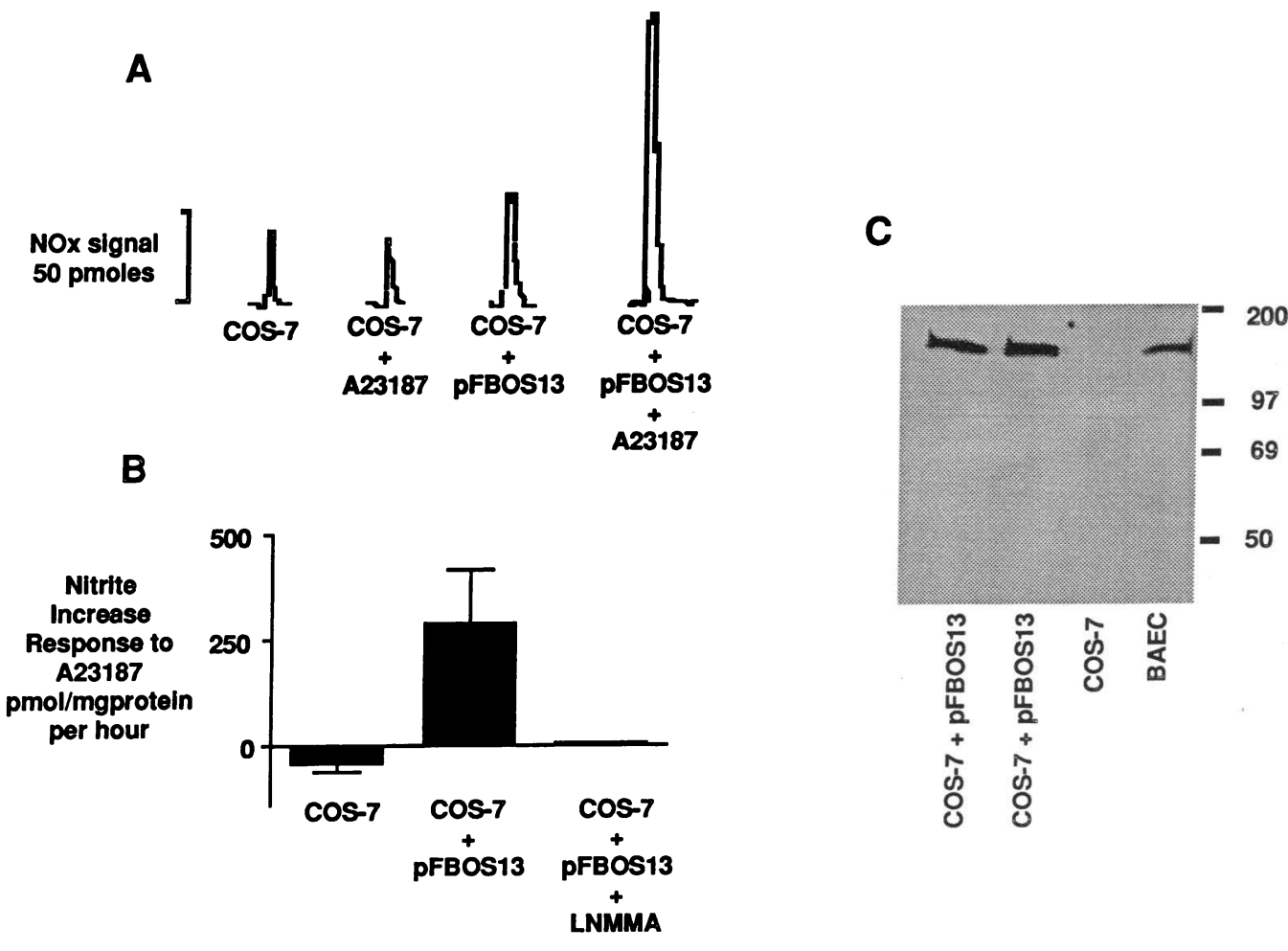

Figure 1. Expression of NO synthase activity in COS-7 cells. Transfection was accomplished using lipofection for $24 \mathrm{~h}$ and the cells were analyzed for nitrite production over a $1-\mathrm{h}$ period in the absence or presence of the calcium ionophore A23187 $(1 \mu \mathrm{M})$. (A) Original tracings of nitrite detection from COS-7 cells untransfected and transfected with pBOS13. Note increase in nitrite production in response to 1 $\boldsymbol{\mu} \mathbf{M}$ calcium ionophore A23187 only in transfected cells. $(B)$ Average production of nitrite in response to A23187 in transfected and untransfected COS-7 cells. Nontransfected COS-7 cells produced minimal quantities of nitrite, but did not increase nitrite production in response to the ionophore. In contrast, both basal and calcium ionophore A23187 stimulated production of nitrite was enhanced after transfection with bovine aortic endothelial cells NO synthase cDNA. L-NMMA inhibited nitrite production from transfected COS-7 cells. ( $n \geq 4$ for all experiments). (C) Western analysis of BAEC NO synthase protein content in COS-7 cells transfected with pFBOS13, untransfected COS-7 cells, and BAEC. Monoclonal antibody against the BAEC NOS was provided by Jennifer Pollock and Ulrich Förstermann (21). 


\section{Results}

Several clones were isolated from the cDNA library and shown to be overlapping by restriction mapping analysis. The largest of these, pBOS 4.1 and pBOS-13, were $4.1 \mathrm{~kb}$ in length. Only pBOS-13 expressed NO synthase activity. Nontransfected COS-7 cells released small quantities of nitrite, but did not release additional nitrite in response to the calcium ionophore A23187. In contrast, COS-7 cells transfected with pBOS-13 released $287 \mathrm{pmol}$ of nitrite/h per $\mathrm{mg}$ protein in response to the calcium ionophore A23187 (Fig. 1, $A$ and $B$ ). Nitrite release in response to the calcium ionophore A23187 was abolished in the presence of L-NMMA. In addition, only COS-7 cells transfected with pBOS-13 expressed a protein detected by an antibody against purified NO synthase (Fig. $1 C$ ).

A 3,615-bp open reading frame begins with the first ATG at residue 30 . This encodes a 1,205 amino acid protein with a calculated relative molecular mass of 133,286 (Fig. 2). This ATG is a stronger candidate for a potential translation initiator than the next downstream ATG beginning at residue 654 (23). The size of this deduced protein is consistent with previous estimates from studies of purified endothelial cell NO synthase (24). Overall, the endothelial cell NO synthase is 58 and $51 \%$ identical to the cloned rat brain and mouse macrophage NO synthases, respectively (15-17). Like these, the deduced endothelial cell NO synthase protein contains amino acid sequences with homologies to binding domains for FMN, FAD, and NADPH. The endothelial cell NO synthase has several unique features. Six potential cAMP-dependent protein kinase phosphorylation sites are present at residues $\operatorname{Ser}_{116}, \operatorname{Ser}_{145}, \operatorname{Ser}_{170}$, $\operatorname{Ser}_{635}, \operatorname{Ser}_{740}$, and $\operatorname{Ser}_{1,053}(25)$. The amino terminus of the endothelial NO synthase is enriched in proline residues. This region also contains many potential phosphate acceptor sites for proline-dependent protein kinase (26). The bovine endo-

A

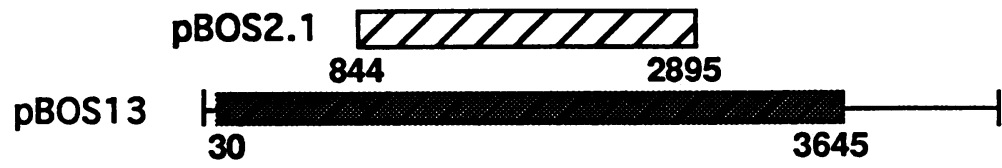

$\mathbf{B}$

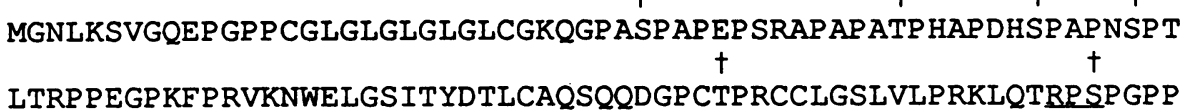
PAEQLLSQARDF INQYYSS IKRSGSQAHEERLQEVEAEVASTGTYHLRESELVFGAKQAW RNAPRCVGR IQWGKLQVFDARDCSSAQEMFTYICNHIKYATNRGNLRSAITVF PQRAPGR $+$ GDFR IWNSQLVRYAGYRQQDGSVRGDP ANVE ITELCIQHGWTPGNGRFDVLPLLLQAPDE APELFVLPPELVLEVP LEHPTLEWFAALGLRWYALP AVSNMLLE IGGLEF SAAPFSGWYM

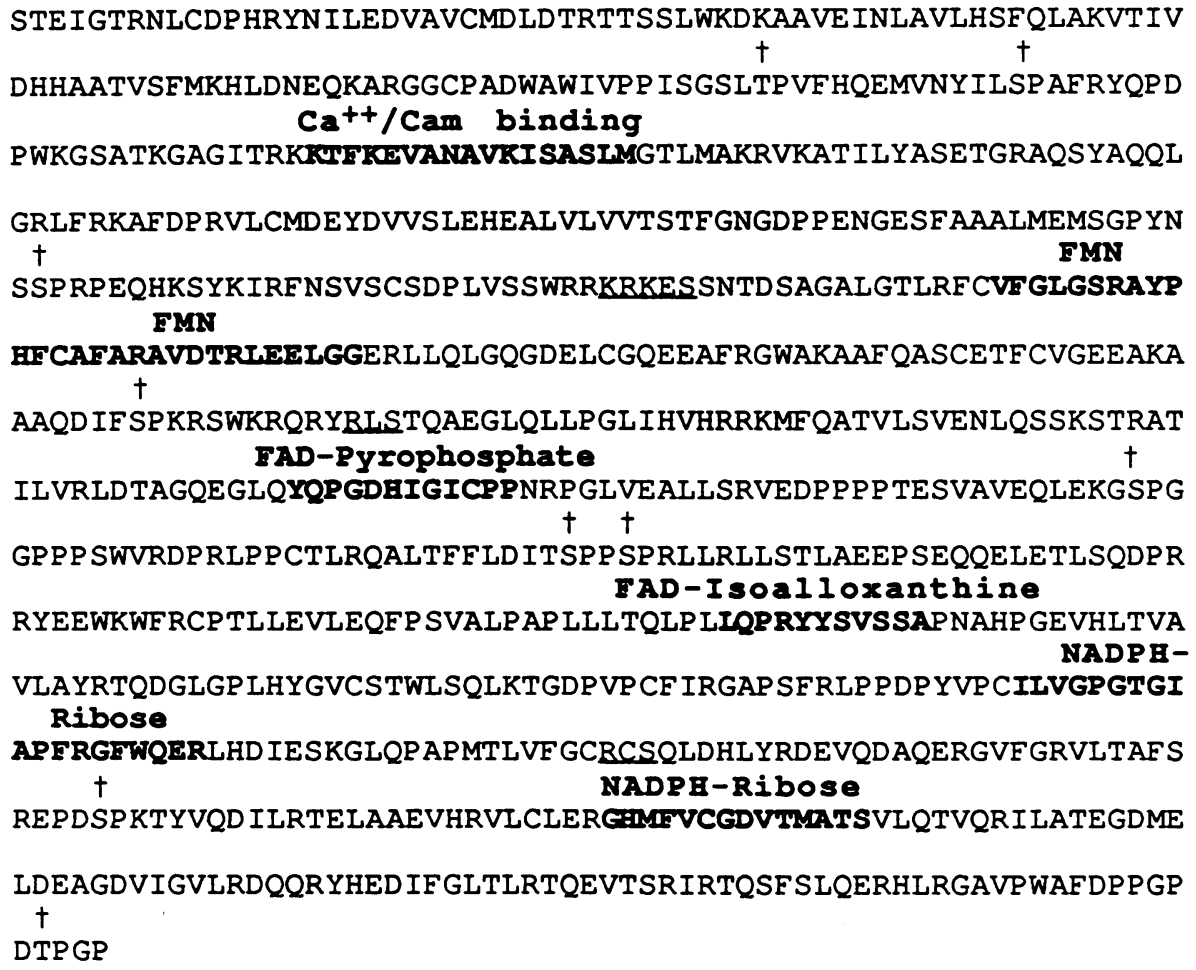

Figure 2. ( $A$ ) Schematic diagram of pBOS13 and pBOS2.1. The shaded area depicts the open reading frame of pBOS13. $(B)$ Deduced amino acid sequence of BAEC NOS. Bold residues are regions with homology to caldium/calmodulin, FMN, FAD, and NADPH binding domains. Underlined sequences denote potential sites of cAMP dependent phosphorylation. *Denotes potential proline directed phosphorylation sites. GenBank accession number M99057. 
thelial cell NO synthase contains no strongly hydrophobic regions, suggesting an absence of membrane binding regions. Importantly, Gly 2 , followed by $\mathrm{Asn}_{3}$ and $\mathrm{Ser}_{6}$, is one of the sequences previously identified to be a substrate for amino terminal myristoylation (27).

Regulation of NO synthase expression in BAEC. Northern analysis of mRNA expression by BAEC in culture revealed an abundant 4.8-kb message (Figs. 3 and 4). Exposure to shear stress of $15 \mathrm{dyn} / \mathrm{cm}^{2}$ substantially increased both NO synthase mRNA and protein expression above that observed in cells not exposed to shear (Fig. $3 A$ ). Exposure to shear also increased expression of NO synthase protein (Fig. $3 B$ ).

TNF $\alpha$ is one of the cytokines known to stimulate production of the inducible NO synthase within various tissues, including the endothelium (26). In contrast to the expected effect of TNF $\alpha$ on expression of the inducible NO synthase, the expression of mRNA identified by pBOS 2.1 was decreased by 24-h exposure to this cytokine (Fig. 4).

\section{Discussion}

We have isolated, characterized, and expressed the endothelial cell NO synthase cDNA. The deduced amino acid sequence of the endothelial cell NO synthase reveals several properties that might be predicted from studies of the purified enzyme including regions with homology to binding domains for flavin adenine nucleotides, flavin mononucleotides, NADPH, and calcium/calmodulin. These cofactors are known to modulate activity of the enzyme purified from the endothelium $(10,14)$, and are shared with both the recently cloned rat cerebellar and mouse macrophage NOS isoforms.

The deduced BAEC NO synthase structure has 58 and $51 \%$ homology to the rat brain and mouse macrophage NO synthases, respectively (15-18). Interestingly, the carboxy-terminal two-thirds of these proteins are highly homologous, while the amino terminal portions are unique to each isozyme. The presence of several acceptor sites for proline-dependent kinase phosphorylation in this region of the bovine NOS may indicate

A

B
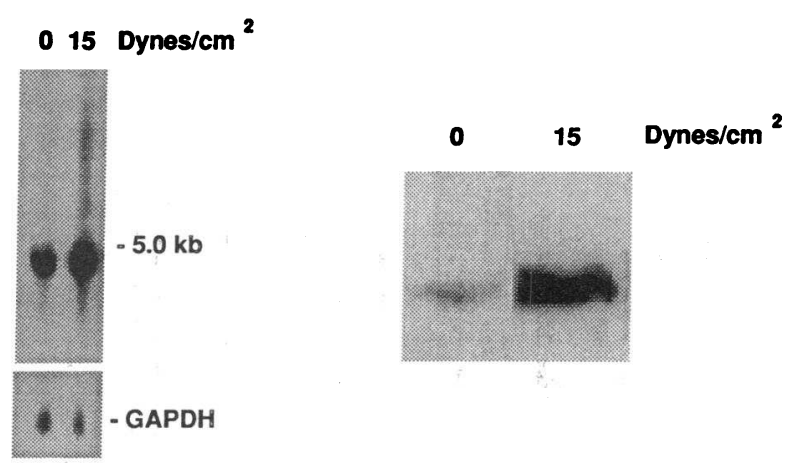

Figure 3. Effect of shear stress on expression of NO synthase. BAEC were grown to confluence on mylar sheets and exposed to either no shear or a shear stress of $15 \mathrm{dyn} / \mathrm{cm}^{2}$ for $24 \mathrm{~h}$. $(A)$ Effect of shear on NO synthase and GAPDH mRNA content. Results were similar in three experiments. $(B)$ Western analysis of NO synthase protein in BAEC exposed to either static conditions or shear stress of $15 \mathrm{dyn} /$ $\mathrm{cm}^{2}$ for $24 \mathrm{~h}$.

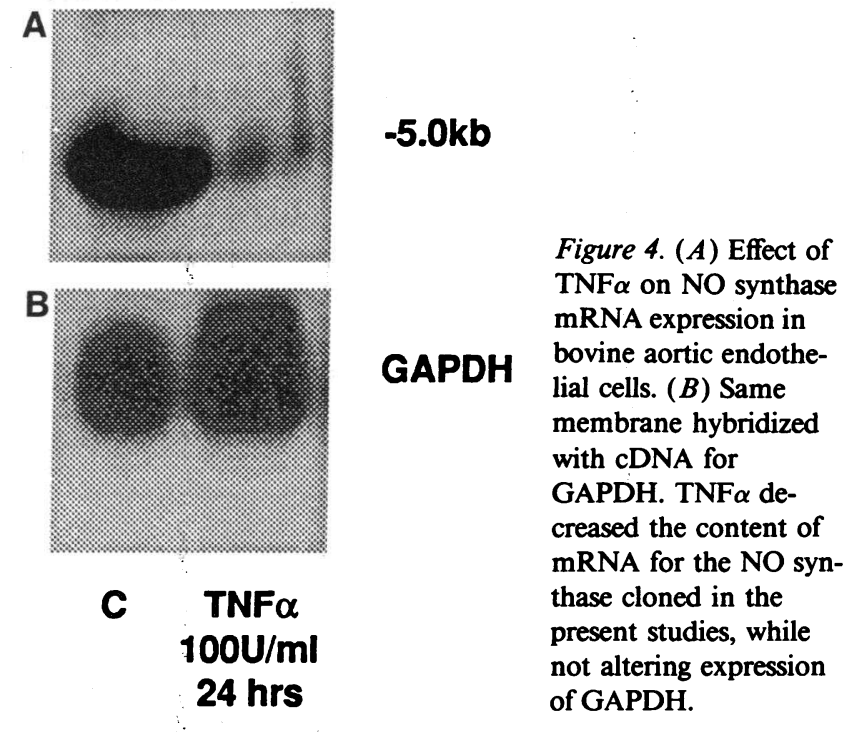

a regulatory mechanism unique to the endothelial cell NO synthase (26).

The endothelium responds to several cytokines and endotoxin by expressing an inducible NO synthase (28). The cDNA isolated and sequenced in these studies does not represent this inducible form of NO synthase. In preliminary studies, cells exposed to TNF $\alpha$ markedly increased production of nitrite, compatible with the induction of NO synthase activity. Despite this, mRNA for the constitutive NO synthase did not increase, but in fact decreased in response to TNF $\alpha$. These findings demonstrate that the NO synthase cloned in these studies is not the cytokine-induced enzyme. The mechanism underlying the decrease in constitutive NO synthase mRNA remains unclear, but may represent either a direct effect of TNF $\alpha$ on transcription or message stability, or an inhibitory effect of the nitric oxide produced by the induced enzyme on the transcription of the constitutive enzyme.

Blood vessels exposed to chronic elevations of shear stress demonstrate augmented endothelium-dependent vascular relaxations, even when removed from the chronic shear environment $(29,30)$. While there are several mechanisms by which this could occur, one might relate to increased expression of NO synthase. Our present studies indicate that this may occur. Exposure of BAEC to $15 \mathrm{dyn} / \mathrm{cm}^{2}$ for $24 \mathrm{~h}$ clearly increased NO synthase expression above that observed in the absence of shear.

Studies of cellular subfractions have shown that the endothelial cell NO synthase is largely $(>80-90 \%)$ associated with the particulate cellular fraction (14). Analysis of the endothelial cell enzyme structure failed to reveal any regions of sufficient size and composition to be compatible with a membranespanning domain. An alternate mechanism of membrane association of proteins involves attachment to fatty acids, particularly myristic acid near the amino terminus. This process is catalyzed via acyl transferases, and the substrates for these have recently been characterized (27). The amino-terminal $\mathrm{Gly}_{2}-\mathrm{Ser}_{6}$ of NO synthase may serve as one such substrate, and may provide a mechanism whereby the enzyme may associate with cellular particulate fractions. Further experiments are needed to confirm this.

The BAEC NO synthase contains several consensus se- 
quences that may be substrates for phosphorylation by protein kinase A (25). Phosphorylation of the brain NO synthase does not alter its activity (31); however, this may not apply to the endothelial cell NO synthase. It has been suggested that substances that increase endothelial cell cAMP concentrations decrease production of the endothelium-derived relaxing factor (32). Indeed, pharmacologic inhibition of prostacyclin production usually does not alter endothelium-dependent vascular relaxation, despite the fact that prostacyclin is a potent vasodilator. The presence of protein kinase A phosphorylation sites on the endothelial NO synthase provides a potential explanation for this observation. It is possible that basally released prostacyclin by activating adenylate cyclase and producing phosphorylation of this region could decrease NO synthase activity. Blockade of prostacyclin production would increase the production of endothelium-derived nitric oxide and compensate for this loss of prostacyclin vasodilatation. In this regard, the two pathways may truly be complementary with regard to regulation of vasomotion. The cloning of the endothelial NO synthase now makes possible structural and mechanistic studies of these regulatory events.

\section{Acknowledgments}

This work was supported by funding from Daiichi Pharmaceuticals, National Institutes of Health grants HL-39006, HL-32717, HL-48252, grant BCS-9111761, and Merit Review funding from the Veterans Administration.

Dr. Navas is a Fellow of the Robert Wood Johnson Foundation, and Dr. Harrison is an Established Investigator of the American Heart Association.

\section{References}

1. Palmer, R. M. J., A. G. Ferrige, and S. Moncada. 1987. Nitric oxide release accounts for the biological activity of endothelium-derived relaxing factor. $\mathrm{Na}$ ture (Lond.). 327:524-526.

2. Myers, P. R., R. L. Minor, R. Guerra, J. N. Bates, and D. G. Harrison. 1990. Vasorelaxant properties of the endothelium-derived relaxing factor more closely resemble S-nitrosocysteine than nitric oxide. Nature (Lond.). 345:161163.

3. Palmer, R. M. J., D. S. Ashton, and S. Moncada. 1988. Vascular endothelial cells synthesize nitric oxide from L-arginine. Nature (Lond.). 333:664-666.

4. Knowles, R. G., M. Palacios, R. M. J. Palmer, and S. Moncada. 1989. Formation of NO from L-arginine in bovine brain cytosol. Proc. Natl. Acad. Sci. USA. 87:682-685.

5. Hibbs, J. B., R. R. Taintor, and Z. Vavrin. 1987. Macrophage cytotoxicity: role for L-arginine deiminase and iminonitrogen oxidation to nitrogen. Science (Wash. DC). 235:473.

6. Schmidt, H. H., R. Seifert, and E. Bohme. 1989. Formation and release of nitric oxide from human neutrophils and HL-60 cells induced by a chemotactic peptide, platelet activating factor and leukotriene B4. FEBS (Fed. Eur. Biochem. Soc.) Lett. 244:357-360.

7. Tayeh M. A., and M. A. Marletta. 1989. Macrophage oxidation of L-arginine to nitric oxide, nitrite, and nitrate. Tetrahydrobiopterin is required as a cofactor. J. Biol. Chem. 264:19654-19658.

8. Stuehr, D. J., S. N. Kwon, and C. F. Nathan. 1990. FAD and GSH Participate in Macrophage Synthesis of Nitric Oxide. Biochem. Biophys. Res. Commun. 168:558-565.

9. Stuehr, D. J., H. J. Cho, N. S. Kwon, M. F. Weise, and C. F. Nathan. 1991. Purification and characterization of the cytokine-induced macrophage nitric oxide synthase: an FAD- and FMN-containing flavoprotein. Proc. Natl. Acad. Sci. USA. 88:7773-7777.
10. Palmer, R. M. J., and S. Moncada. 1989. A Novel Cirtulline-Forming Enzyme Implicated in the Formation of Nitric Oxide by Vascular Endothelial Cells. Biochem. Biophys. Res. Commun. 158:348-352.

11. Bredt, D. S., and S. H. Synder. 1990. Isolation of nitric oxide synthetase, a calmodulin-requiring enzyme. Proc. Natl. Acad. Sci. USA. 87:682-685.

12. Busse, R., and A. Mülsch. 1990. Calcium-dependent nitric oxide synthesis in endothelial cytosol is mediated by calmodulin. FEBS (Fed. Eur. Biochem. Soc.) Lett. 265:133-136.

13. Yui, Y., R. Hattori, K. Kosuga, H. Eizawa, K. Hiki, S. Ohkawa, K. Ohnishi, S. Terao, C. Kawai. 1991. Calmodulin-independent nitric oxide synthase from rat polymorphonuclear neutrophils. J. Biol. Chem. 266:3369-3371.

14. Förstermann, U., J. S. Pollock, H. H. H. W. Schmidt, M. Heller, and F. Murad. 1991. Calmodulin-dependent endothelium-derived relaxing factor/nitric oxide synthase is present in the particulate and cytosolic fractions of bovine aortic endothelial cells. Proc. Natl. Acad. Sci. USA. 88:1788-1792.

15. Bredt, D. S., P. M. Hwang, C. E. Glatt, C. Lowenstein, R. R. Reed, and S. H. Snyder. 1991. Cloned and expressed nitric oxide synthase structurally resembles cytochrome P-450 reductase. Nature (Lond.). 351:714-718.

16. Xie, Q. W., H. J. Cho, J. Calaycay, R. A. Mumford, K. M. Swiderek, T. D. Lee, A. Ding, T. Troso, and C. Nathan. 1992. Cloning and characterization of inducible nitric oxide synthase from mouse macrophages. Science (Wash. DC). 256:225-228.

17. Lyons, C. R., G. J. Orloff, and J. M. Cunningham. 1992. Molecular cloning and functional expression of an inducible nitric oxide synthase from a murine macrophage cell line. J. Biol. Chem. 267:6370-6374.

18. Mizushima, S., and S. Nagata. 1990. pEF-BOS, a powerful mammalian expression vector. Nucleic Acids Res. 18:5322.

19. Sanger, F., S. Nicklen, and A. R. Coulson. 1977. DNA sequencing and chain terminating inhibitors. Proc. Natl. Acad. Sci. USA. 74:5463-5467.

20. Bradford, M. M. 1976. A rapid and sensitive method for the quantification of microgram quantities of protein utilizing the principle of protein-dye binding. Anal. Biochem. 72:248-254.

21. Pollock, J. S., M. Nakane, D. R. Springall, Z.-J. Haung, J. A. Mitchell, T. D. Warner, J. M. Polak, U. Förstermann, and F. Murad. 1992. Particulate and Soluble Endothelial Nitric Oxide Synthase are Structurally Similar Proteins. J. Vasc. Res. 29:184.

22. Levesque, M. J., and R. M. Nerem. 1985. The elongation and orientation of cultured endothelial cells in response to shear stress. J. Biomech. Eng. 107:341-347.

23. Kozak, M. 1986. Point mutations define a sequence flanking the AUG initiator codon that modulates translation by eukaryotic ribosomes. Cell. 44:283292.

24. Pollock, J. S., U. Förstermann, J. A. Mitchell, T. D. Warner, H. H. Schmidt, M. Nakane, and F. Murad. 1991. Purification and characterization of particulate endothelium-derived relaxing factor synthase from cultured and native bovine aortic endothelial cells. Proc. Natl. Acad. Sci. USA. 88:10480-10484.

25. Kemp, B. E., and R. B. Pearson. 1990. Protein kinase recognition sequence motifs. Trends Biol. Sci. 15:342-346.

26. Hall, F. L., and P. R. Vulliet. 1991. Proline directed protein phosphorylation and cell cycle regulation. Curr. Opin. Cell Biol. 3:176-184.

27. Towler, D. A., S. R. Eubanks, D. K. Towery, S. P. Adams, and L. Glaser. 1986. Amino-terminal processing of proteins by N-myristoylation. J. Biol Chem. 262:1030-1036.

28. Gross, S. S., E. A. Jaffe, R. Levi, and R. G. Kilbourne. 1991. Cytokine-activated endothelial cells express and isotype of nitric oxide synthase which is tetrahydrobiopterin dependent, calmodulin-independent and inhibited by arginine analogs with a rank order of potency characteristic of activated macrophages. Biochem. Biophys. Res. Commun. 178:823-829.

29. Miller, V. M., L. L. Aarhus, and P. M. Vanhoutte. 1986. Modulation of endothelium-dependent responses by chronic alterations of blood flow. Am. J. Physiol. (Heart and Circ. Physiol.). 251:H250-257.

30. Miller, V. M., and P. M. Vanhoutte. 1988. Enhanced release of endothelium-derived factor(s) by chronic increases in blood flow. Am. J. Physiol. (Heart and Circ. Physiol.). 255:H446-0451.

31. Bredt, D. S., C. D. Ferris, and S. H. Snyder. 1992. Nitric oxide synthase regulatory sites. Phosphorylation by cyclic AMP-dependent protein kinase, protein kinase $\mathrm{C}$, and calcium/calmodulin protein kinase; identification of flavin and calmodulin binding sites. J. Biol. Chem. 267:10976-10981.

32. Luckhoff, A., A. Mulsch, and R. Busse. 1990. cAMP attenuates autacoid release from endothelial cells: relation to internal calcium. Am. J. Physiol. (Heart Circ. Physiol.). 258:H960-H966. 